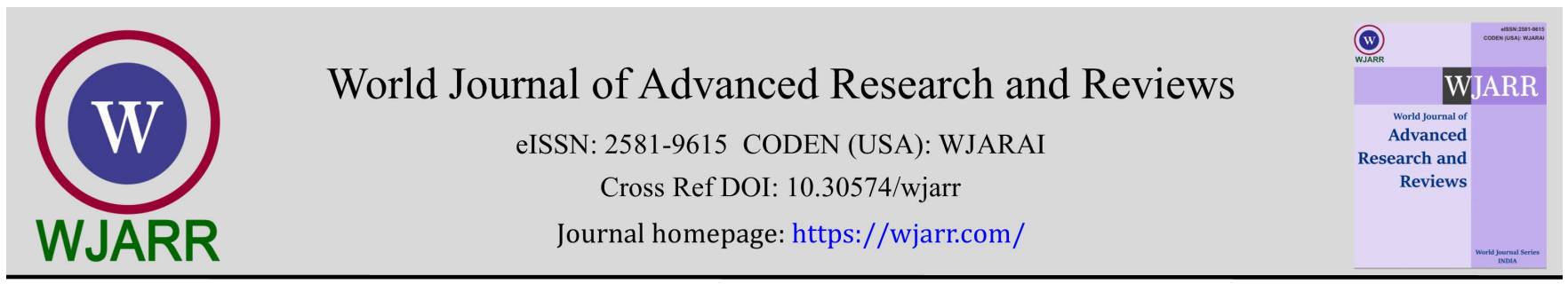

(REVIEW ARTICLE)

\title{
Corporate social responsibilities of international oil companies as a panacea to conflict management in selected host communities in southern Nigeria
}

\author{
Kenneth Chisom Gbali 1, Vincent Ezikornwor Weli ${ }^{2,}{ }^{*}$ and Prince Chinedu Mmom ${ }^{2}$ \\ ${ }^{1}$ center for disaster Risk Management and Development Studies, University of Port Harcourt, Port Harcourt, Nigeria. \\ 2 Department of Geography and Environmental Management, University of Port Harcourt, Port Harcourt, Nigeria.
}

World Journal of Advanced Research and Reviews, 2021, 11(03), 351-362

Publication history: Received on 11 August 2021; revised on 25 September 2021; accepted on 27 September 2021

Article DOI: https://doi.org/10.30574/wjarr.2021.11.3.0443

\begin{abstract}
The study examined corporate social responsibility and management of Oil-related conflicts in South-South Nigeria. The CSR was seen as rooted in the relationship between employee, business and State-social relationship. The aim of the study is to examine the level of relationship between the oil companies and the host communities. Objectives to Investigate the CRS programs carried out by IOC's in the host communities, Ascertain the significance of CSR as conflict management strategy by IOC's to the host communities, Evaluate the factors affecting the implementation of the CSR by some IOC's in the region. The population of the study area was 2,358,000. The Taro Yamene formula for sample size determination was used to arrive at 400 for the study of the 27 host Communities. Three core oil producing States were selected. Out of these three State, three Local Government areas and three communities each based on their oil producing capacity. Data collection was semi-structured: questionnaire interviews, focused group discussion. Secondary data was by reports, books, and journals. Descriptive tool such as frequency, mean, standard deviation, tables and maps was used to answer research questions. The statistical tool for hypothesis testing was independent $\mathrm{T}$ test. The study revealed that frequent conflicts in the study area have been characterized by the relationship between Oil prospecting Companies and their host communities; a close look at the conflicts shows that most of such have direct or indirect link with IOC's, as a result of inadequate CSR management. Some recalcitrant cash-in by way of vandalism, etc., others through legitimate agitations. The impacts of a supposed sustainable development of oil and gas exploration in the area is hitherto environmental degradations, e.g. effluents, unemployment, lack of social amenities, non-inclusion. The study recommended a practicable participatory paradigm shift, where planning with the Community will be mainstreamed.
\end{abstract}

Keywords: Oil related conflicts; Oil producing companies; Host communities; Corporate social responsibility; Environmental degradation

\section{Introduction}

The activities of the International Oil Companies (IOC) have resulted to instabilities, crisis, protests by host Communities, and Environmental degradations, lack of employment, poverty and lack of social development in the South-South region [1], [2], [3]. Sometimes in March 2012, the Youth of Ndoki in Oyigbo LGA of Rivers State carried out a protest against the activities of SPDC in the area.

While the story told to consumers of Nigerian crude in the United States and the European Union countries and other public relations efforts is that oil companies are a positive force in Nigeria, providing much needed economic development resources, studies have pointed at non-participation of host communities in connection to conflicts in oil exploratory activities. These corporations' acts of charity and development are slaps in the face of those they claim to

\footnotetext{
* Corresponding author: Vincent Ezikornwor Weli

Department of Geography and Environmental Management, University of Port Harcourt, Port Harcourt, Nigeria.
}

Copyright (C) 2021 Author(s) retain the copyright of this article. This article is published under the terms of the Creative Commons Attribution Liscense 4.0. 
be helping. Far from being a positive force, these oil companies presence are eliciting divergent views from various stakeholders; the host communities making up the value chain and in their own perception as integral. Violence in the South-South of Nigeria claims a substantial number $f$ life's each year, with over 50 years of presence in Nigeria, it is reasonable to say that the Companies in Nigeria have become integral part of the South-South conflicts. [4]

The bitter experience of the Oil producing areas in Nigeria generally has been both unprecedented and indeed regrettable.

According to Okonta (2007) [5], conflicts in the region cannot be understood without taking into account the historical background of International economic forces associated with oil exploitation, which the host communities have tried to resist. Historical sources, without doubt states that the impact of environmental degradation is traceable to the activities of IOC's with relative remedial measures to enhance natural attenuation. These activities on the environment, affects the ecology with a resultant low agricultural output, fishing and the entire economic life of the people.

In describing the South-South region, [6] argue that the region is undoubtedly the richest part of Nigeria in terms of natural resources. In their view: the area has large oil and gas deposits, as well as extensive forests, good agricultural land and abundant fish resources. Despite the tremendous natural and human resources base, the regions potential for sustainable development remains unfulfilled and its future is being threatened by environmental degradation and deteriorating economic conditions which are not being addressed by past and present policies and actions. The quest and development of oil resources in most host communities of the Southern Nigeria have shown a gap in comparative benefit in the area.

Conflicts is endemic in every society, conflicts in the South-South predates the advent of oil exploration, but the source and magnitude of occurrence is still questioned to have escalated with the coming of trans-National Companies in the early 90's.

The Concept of Corporate social responsibility (CSR) in the whole World is recent about 60years. Prior to this period, there were different standards and regulations in the areas of Corporate Governance, Corporate ethics, and relationships with competitors, responsibilities towards the society and the Country [7]. Social policy rules and standards have not been developed at all because there was use of "random approach". However, from the late 60's70's leading U.S and European Companies have started to come to an understanding of the need to unite different elements of corporate policies related to the relationship of the Company with the Environment, and to the development of a single integrated approach to interaction with society. Such a policy on the one hand would have to be associated with the philosophy of the Company, it marketing strategy, and it should meet the expectation of Society.

The report of the U.N Secretary General Kofi Annan in 2012, "Development of guidelines on the role and social responsibility of the private sector", states that the presence of the big companies a certain manifesto on corporate social responsibility becomes a prerequisite for any successful Corporate communication and public relations strategy. In this contemporary time, the practice of Corporate Social Responsibility is now an important part of business organization which encourages a lot of gains in the future [8].

Businesses are realizing that in order to stay profitable in a rapidly changing environment, they would have to become socially responsible. Therefore, the belief that beyond making profit for the shareholders, business enterprises should also serve the interests of all other stakeholders has culminated into the concept of Corporate Social Responsibility (CSR) [9]. It Is the persistent commitment by a business organization to ethically behave to contribute maximally to the economic and environment advancement of the quality of life its workforce and the society, particularly the host communities. What is noteworthy is that it has moved beyond local or national arenas and become the subject of global attention. That is the role of business in relationship to the State, Locally and nationally, as well as inter-State institutions or standards; and business performance as a responsible member of the society in which it operates and the global Community. Too often, attaining CSR is understood from the perspectives of business generosity to Community projects and charitable donations, but this fails to capture the most valuable contribution that Company has to take.

The World business council for sustainable development stresses CSR as the continuing commitment by business to behave ethically and contribute to economic development while improving the quality of life of the workforce and their fair families, as well as of the community and society at large. CSR is a concept that an enterprise is accountable for its impact on all relevant stakeholders. Globally, organizations are concerned with value re-investment to the society in appreciation of the contribution of the society to their growth, sustenance and survival. Hence attention to CSR starts with a 'Company's value system and a principled approach to doing business. This means operating in ways that, at a minimum, meet fundamental responsibilities in the areas of human rights, labour, environment and anticorruption. 
Responsible business enacts the same value and principles wherever they have a presence, and establishing a culture of integrity, companies are not only upholding their basic responsibilities to the people and planet, but also setting the stage for long term success. The international labour organization declaration on Environmental and development and the United Nations convention against corruption (www.unglobalcompact.org). The connection between the bottom line and a Company's environmental policy, social and governance practices is becoming clear. Businesses are responding, moving beyond their basic responsibility and going further into a global compact, as the World largest global cooperate sustainability initiative, with over 8000 companies and 4000 non-business participants based in over 160 Countries [10]. A vanguard of Companies in all key markets is taking key action. Multinational Companies all over the globe representing every industry sector and size, from both developed and developing Countries are participants. Cooperate social Responsibility is enshrined into the United Nations Compact which principle activities include Environmental and Educational projects. This Principle rein- enforces social, environmental and economic fairness worldwide. Children and Youths through education enhance their chances. Schools and kindergarten gets excited about science and technology because excitement is the first step to acquiring critical skills. The United Nations concept has ten (10) principles, grouped into four subsections. Given this as the trust of operation, cooperate attention is increasingly being given to issues like equal employment opportunity: 1 Human right principle (1-2), 2. Labour (3-6), 3. Environment (7-9), 4 Anti-corruptions (10). This is easier for cooperation's to be reoriented to corporate social responsibility philosophies (International Review of social sciences and humanities.

It has become a component of broader debates on development and poverty reduction in underdeveloped nations, particularly in relation to the lack of governance in many places. The topic of corporate social responsibility (CSR) is at the forefront of strategic thinking in the business world. Corporate accountability is nearly a foregone conclusion of societal development. When it comes to the behaviour of multinational oil and gas extracting businesses, the subject has been particularly contentious. Most international oil companies and their operations in Nigeria's South-South region, or Niger Delta, have been the centre of attention; consequently, attention will be concentrated on the three South-South states of Rivers, Bayelsa, and Delta, where the majority of IOCs are based and in relations to their production capacity. Communities in the South-South have been increasingly investigated in relation to the activities of major IOCs in the area and its attendant environmental degradation, ongoing conflicts, violence, and poverty. This study is based on the ongoing discussion about the impact of Multinational or international oil companies (IOCs) and foreign direct investment (FDI) in developing countries [11]. Simply put, some argue that ICOs can contribute to economic and social growth through investment, employment, taxation, and the transfer of technology, knowledge, and skills. Others point out that IOCs have been heavily involved in promoting a kind of "development" and North-South ties that has harmed the people and environment of many developing countries. However, when it comes to carrying out their societal tasks, IOCs have a tendency to use double standards. Their standard in the West is not the same as the one they follow in Africa, notably Nigeria. Shell's failure to repair a leak in the North Sea, for example, resulted in the resignation of its US chairman. However, the company's documented oil leaks in the Niger Delta in 2009 were estimated to be 14,000 barrels per day, compared to 1,300 barrels per day in the North Sea. The level of pollution in the Niger Delta has not resulted in a complete clean-up, and no one in the corporate structure has accepted responsibility. Businesses, on the other hand, function inside a society, and their waste products are likewise discharged within that society [12]. When garbage is not properly channeled and societal implications are ignored, it becomes a problem. As previously stated, the Niger Delta's violence, poverty, and environmental damage are the outcome of a complicated history in which Shell's oil extraction as a leading global oil company has played a crucial role. The IOC's activities have caused extensive harm to small-scale fishing and farming, destroying livelihoods in the Delta. Furthermore, the SPDC, as well as other IOCs such as Chevron, Mobile, and Total, have undoubtedly contributed to the region's growing militarism, not only by inciting societal discontent, but also by directly supporting and paying community groups to militarise in the hopes of protecting the company's infrastructure [13]. Despite this, the companies address concerns like environmental degradation and poverty as if they were a pre-existing calamity that had nothing to do with the company's operations. This inability to accept responsibility contributes significantly to the Delta residents' strong (and historically grounded) hatred of Shell. The current investigation is focused on identifying an appropriate conflict management strategy to model after what has been done in other regions of the world [14] in order to ensure mutual peaceful cohabitation between prospecting firms and their host communities [15].

Clarification and comprehension of the foundations for any recommended course of action in this area will benefit us in charting our future courses. As a result, the important aspects of this subject will elicit ideas and debate, which would hopefully link corporate responsibility to our society's desperate need for innovation, leading to the development and widespread application of the principles in Nigeria. 


\section{Statement of the Problem}

The South-South region of Nigeria is the epicentre of most oil and gas activities in the Country, prominent among the conflicts in the area are premised on the laws, regulations and practices in oil exploitation and participation, landownership. Lack of corporation to tackle the problem and reduce the effects of drilling activities on the environment and raise the standard of living of the people in the host communities became a source of concern to the youth of the region 16]. While it might not be right to argue that the oil Multinational companies have done nothing in the realm of CSR but bring the host communities a curse, it will be wrong to agree that the IOC's have done enough. The basis for the above premise is that various CSR strategies have been adopted by the IOC's overtime

It has been observed that over the years, the people of South-South region have constantly argued at various fora that resource control and integration are the basis of the problems of the region [17],[18] study further suggests that as far as the South-South is concerned, the recurrent challenges of violence and restiveness are man induced and as a result of gross negligence, non-integration and mainstreaming of the people, which is the sine qua non for sustainable peace and development in Nigeria. That the militarisation of the region has not helped in restoring the much-desired stability in this regard raises a question of the government's conflict management style. In spite of the interventionist measures adopted, the aggrieved communities seem not to be appeased by the Nigerian oil industry. In the context of developing countries, it has become part of broader debate on development and poverty reduction, the subject matter CSR is the cutting edge of strategic thinking in business community. Corporate social responsibility is almost an inevitable resort of societal evolution.

The absence of workable Cooperate Social Responsibility, institutional and financial mechanism, all tend to have provided the root-cause for agitation and exacerbation of militancy and activism in the region. As most of the conflicts in South-South region has been adduced to be caused by human negligence, to minimize and reduce the conflicts that result between Oil producing Companies and host Communities and enable organizations engage in the development of the host communities, the nexus between CSR becomes obvious, [19].

Although, there has been claims on an upsurge in "voluntary initiatives" associated with codes of conduct, improvements in environmental management systems, improved health and safety standards, company reporting on social and environmental policy and performance, participation in certification and labelling schemes, an increase in corporate social investment in, for example, community development projects, and philanthropy. Large companies in the South-South such as SPDC seeming to be participating in so-called Global memorandum of Understanding (GMOU), which anchors on "multi-stakeholder initiatives" and "public-private partnerships" with NGOs and governmental or multilateral organizations, which to them seem to represent the concept of CSR; but adoption of CSR was not simply a corporation-led movement. Rather, it was part of a paradigm shift in the thinking of development practitioners within a new world order where 'rolling back' incompetent states provided space for a far greater role for the private sector in all areas of life. Included in this thinking was the potential for self-regulated CSR by industries to contribute to development goals. This think piece has revealed some problems with this thinking. In this particular case, the complex nature of the challenges facing the host communities requires a multifaceted approach. Secondly, it is clear that major players in the oil industry do not have a clear framework and therefore faces severe organizational constraints in designing and implementing successful CSR.

\section{Aim and objectives}

The aim of this study is to examine the Corporate Social Responsibilities of IOCs as a panacea to conflict Management strategy in selected host Communities in the South-South States.

The Specific Objectives Includes the Following:

- Ascertain the conflict management strategies adapted by International Oil companies to the host Communities to mitigate conflicts.

- Evaluate the factors affecting the implementation of the CSR by some IOCs in host communities in South-South of Nigeria.

- Determine the extent CSR programmes of oil producing companies have promoted better relationship with host communities in South-South, Nigeria?

\section{Research Question}

- What are the conflict management strategies adopted by IOCs to the host Communities to mitigate conflicts? 
- What are the factors affecting the implementation of the CSR by some IOCs in host communities in SouthSouth of Nigeria?

- To what extent has CSR programmes of oil producing companies promoted better relationship with the host communities in the South-South, Nigeria?

\section{Hypotheses}

The following hypothesis was formulated based on the objectives and problems of this research.

Ho1: There is no significant difference in the mean rating of male and female respondents on the significance of CSR as conflict management strategies by IOC'S to the host Communities in South-South, Nigeria.

$\mathbf{H O}_{2}$ : There is no significant difference in the mean ratings of male and female respondents on factors affecting the implementations of CSR by some IOC'S in host Communities of South-South, Nigeria.

Ho $:$ There is no significant difference in the mean ratings of male and female respondents on the extent CSR programs of Oil producing Companies has promoted better relationship with host Communities in the South-South of Nigeria.

\section{Conceptual review}

\subsection{Corporate Social Responsibility (Csr)}

Evolution of the concept of CSR passed certain stages, the starting point can be considered as G. Bowens, "Social Responsibility Businessman", which was published in (1953). Where they specified the concept and content of social responsibility. In other words, CSR refers to an oil company's transparent business practices that are based on ethical values compliance with legal requirements, and respect for people, communities and the environment.CSR is a means by which companies can frame their attitudes and strategies towards, and relationships with, stakeholders, be they investors, employees or, communities, within a popular and acceptable concept.

\section{2. corporate social responsibility in the exploration industry}

There are a number of business reasons aside from external pressure why Multinational companies invest in communities through their CSR programmes. [20] outlines these as: Obtaining a competitive advantage - community investment programmes are used to aid the awarding of concessions as companies appearing to be socially responsible are often favoured in this process, Receiving and maintaining a stable working environment - CSR initiatives are occasionally initiated as a means of 'buying' the local communities' agreement to allow a company to operate, Managing external perceptions and maintaining a good reputation - CSR initiatives are used for PR purposes and keeping employees happy - CSR initiatives can often make staff feel more positive about the company, and can increase motivation and efficiency. They can also help to retain and recruit the best staff. A key stakeholder for all Multinational companies, and therefore a strong focus for their CSR initiatives, is 'the community'. IOCs has a huge impact on local communities; positive effects include the creation of new communities and wealth, income from export revenues and royalties, technology transfer, skilled employment and training for local populations and improvements in infrastructure such as roads, schools and health clinics [21]. [22].

\section{Methodology}

The study employed the exploratory and descriptive research design and the study was conducted in three of the SouthSouth states which comprises of Delta, Bayelsa, Rivers State. The population of the study comprised of 2,358,000 residents Nigeria population Commission [23]. The sample size for the study was four hundred (400) and this was determined using the Taro Yamane formula. The multi-stage sampling technique which comprised of stratified sampling, random sampling, and purposive sampling were used to select four hundred respondents from the population for the study. Data for the study was derived via primary and secondary sources. Primary data was derived using a set of structured questionnaires, interview, and Focused Group Discussion. Secondary data for the study was derived from published project material, journals, memorandum of understanding, newspapers, and online blogs, amongst others.

The main method for data collection used in this study was structured questionnaire, semi-structured interviews, participant observation, group discussion, secondary source analysis and questionnaires. The instruments for the study were validated through constructive suggestions by the supervisor for corrections and final approval, and the reliability of the instrument was determined using the Cronbach Alpha reliability test, and a reliability coefficient of 0.87 was 
derived. Data derived from the study were sorted, coded and analysed using the Statistical Package for Social Sciences (SPSS) version 23.0. descriptive statistical tools such as mean and standard deviation were used to respond to the research questions, while students T-test statistical tool was used to test the hypotheses.

\section{Findings And Result of Study}

Research Question 1: What are the conflict management strategies adopted by IOCs to the host Communities to mitigate conflicts?

Table 1 Mean ratings of respondents on the conflict management strategies adopted by IOCs to mitigate between oil companies and host Communities

\begin{tabular}{|l|l|c|c|c|}
\hline S/N & Items & (X) & SD & Decision \\
\hline 1 & Regular consultation & 2.78 & 0.89 & $\mathrm{~A}$ \\
\hline 2 & Carrying out developmental projects & 2.64 & 0.87 & $\mathrm{~A}$ \\
\hline 3 & Giving incentives to Chiefs and opinion leaders & 2.50 & 0.87 & $\mathrm{~A}$ \\
\hline 4 & $\begin{array}{l}\text { Participation in decision making by host communities on community } \\
\text { related issues }\end{array}$ & 2.54 & 0.76 & $\mathrm{~A}$ \\
\hline 5 & Provision of social amenities & 2.55 & 0.88 & $\mathrm{~A}$ \\
\hline \multicolumn{2}{|l|}{ Grand Mean } & 2.60 & 0.85 & $\mathrm{~A}$ \\
\hline
\end{tabular}

Table 1 showed the mean ratings of respondents on the conflict management strategies adopted by IOCs to mitigate conflicts between oil companies and host Communities in South-South of Nigeria. Findings from the table showed a grand mean and standard deviation scores of 2.60 and .85 implies that respondents agree that the conflict management strategies adopted by IOCs to mitigate conflicts between oil companies and host Communities in South-South of Nigeria are: regular consultation, carrying out developmental projects, giving incentives to Chiefs and opinion leaders, participation in decision making by host communities, and provision of social amenities.

Research Question 2: What are the factors affecting the implementation of the CSR by some IOCs in host communities in South-South of Nigeria?

Table 2 Mean ratings of respondents on factors affecting the implementation of the CSR by Some IOCs in host communities South-South of Nigeria

\begin{tabular}{|c|l|l|l|l|}
\hline S/N & Items & (X) & SD & Decision \\
\hline 6 & Vandalization of facilities & 2.80 & 0.89 & $\mathrm{~A}$ \\
\hline 7 & Volatile nature of host communities & 2.71 & 1.01 & $\mathrm{~A}$ \\
\hline 8 & Autocratic approach of IOCs to host communities & 2.68 & 0.68 & $\mathrm{~A}$ \\
\hline 9 & Hostile nature of host communities & 2.52 & 0.76 & $\mathrm{~A}$ \\
\hline 10 & Policies of IOCs on project implementation & 2.81 & 0.92 & $\mathrm{~A}$ \\
\hline \multicolumn{2}{|r|}{ Grand Mean Dec=Decision; A=Agree } & 2.70 & 0.85 & $\mathrm{~A}$ \\
\hline \multicolumn{2}{|r}{} \\
\hline
\end{tabular}

Table 2 showed the mean ratings of respondents on factors affecting the implementation of the CSR by some IOCs in host communities South-South of Nigeria. The table showed a grand mean and standard deviation scores of 2.70 and .85 which implies that respondents agree that the factors affecting the implementation of the CSR by some IOCs in host communities South-South of Nigeria are: vandalization of facilities, volatile nature of host communities, autocratic approach of IOCs to host communities, hostile nature of host communities, and policies of IOCs on project implementation. 
Research Question 3: To what extent has CSR programmes of oil producing companies promoted better relationship with the host communities in the South-South, Nigeria?

Table 3 Mean ratings of respondents on the extent CSR programmes of oil producing companies have promoted better relationship with the host communities in South-South of Nigeria

\begin{tabular}{|c|l|c|c|c|}
\hline S/N & Items & (X) & SD & Decision \\
\hline 11 & CSR protects oil producing firms' reputations in the host communities & 2.83 & 0.83 & $\mathrm{HE}$ \\
\hline 12 & IOC's considers host communities welfare benefits over profit & 3.03 & 0.73 & $\mathrm{HE}$ \\
\hline 13 & CSR integrates stake holders into oil companies and host communities & 2.83 & 0.84 & $\mathrm{HE}$ \\
\hline 14 & CSR promotes harmony between oil companies and host communities & 2.79 & 0.91 & $\mathrm{HE}$ \\
\hline 15 & CSR helps oil companies to manage risks in business & 2.71 & 0.69 & $\mathrm{HE}$ \\
\hline & Grand Mean & 2.83 & 0.80 & $\mathrm{HE}$ \\
\hline
\end{tabular}

Dec=Decision; HE=High Extent

Table 3 showed the mean ratings of respondents on the extent CSR programmes of oil producing companies have promoted better relationship with the host communities in South-South of Nigeria. The table showed a grand mean and standard deviation scores of 2.83 and .80 which implies that respondents are of the opinion that to a high extent, CSR programmes of oil producing companies have promoted better relationship with the host communities in South-South of Nigeria.

\subsection{Test of hypotheses}

Ho1: There is no significant difference in the mean rating of male and female respondents on CSR as conflict management strategies by IOC'S to the host Communities in South-South, Nigeria.

Table 4 Independent Samples Test for male and female respondents on the significance of CSR as conflict management strategies by IOC'S in the host Communities of South-South, Nigeria

\begin{tabular}{|c|c|c|c|}
\hline & & \multicolumn{2}{|c|}{$\begin{array}{l}\text { Significance of CSR as conflict } \\
\text { management strategies }\end{array}$} \\
\hline & & $\begin{array}{c}\text { Equal } \\
\text { variance } \\
\text { assumed }\end{array}$ & $\begin{array}{c}\text { Equal } \\
\text { variance not } \\
\text { assumed }\end{array}$ \\
\hline $\begin{array}{c}\text { Lavene's Test for Equality of } \\
\text { Variances }\end{array}$ & $\begin{array}{c}\text { F } \\
\text { Sig. }\end{array}$ & $\begin{array}{l}0.086 \\
0.769\end{array}$ & \\
\hline \multirow[t]{5}{*}{ t-test for Equality of Means } & $\mathrm{t}$ & -0.311 & -0.311 \\
\hline & $\mathrm{df}$ & 401 & 394.406 \\
\hline & $\begin{array}{l}\text { Sig.(2-tailed) } \\
\text { Mean Difference }\end{array}$ & $\begin{array}{l}0.756 \\
-0.11584\end{array}$ & $\begin{array}{l}0.756 \\
-0.11584\end{array}$ \\
\hline & $\begin{array}{ll}\text { Std. } & \text { Error } \\
\text { Difference } & \end{array}$ & 0.37222 & 0.37284 \\
\hline & $\begin{array}{l}95 \% \text { Confidence } \\
\text { Lower } \\
\text { interval of the } \\
\text { difference Upper }\end{array}$ & $\begin{array}{l}0.84760 \\
0.61591\end{array}$ & $\begin{array}{l}0.84884 \\
0.61715\end{array}$ \\
\hline
\end{tabular}

Table 4 showed that the group means are statistically insignificant because the value for equal variance assumed in the sig. (2-tailed) row is greater than 0.05 that is $(P=.756>0.05)$, $\mathrm{df}(400)=.394 .406, \mathrm{p}=.756$. Therefore, the null hypothesis 
of no significant difference in the mean rating of male and female respondents on significance of CSR as conflict management strategies by IOC's in host Communities in South-South Nigeria is rejected. This implies that there is a significant difference in the mean ratings of male and female respondents on the on Significance of CSR as conflict management strategies by IOC's in hosts Communities in South-South, Nigeria.

$\mathbf{H O}_{2}$ : There is no significant difference in the mean ratings of male and female respondents on factors affecting the implementations of CSR by some IOC'S in host Communities of South-South, Nigeria

Table 5 Independent Samples Test for male and female respondents on the factors affecting the implementation of CSR by some IOC'S in host Communities of South-South, Nigeria

\begin{tabular}{|c|c|c|c|}
\hline & & \multicolumn{2}{|c|}{$\begin{array}{l}\text { Factors affecting the } \\
\text { implementation of CSR }\end{array}$} \\
\hline & & $\begin{array}{c}\text { Equal } \\
\text { variance } \\
\text { assumed }\end{array}$ & $\begin{array}{c}\text { Equal } \\
\text { variance not } \\
\text { assumed }\end{array}$ \\
\hline $\begin{array}{c}\text { Lavene's Test for Equality } \\
\text { of } \\
\text { Variances }\end{array}$ & $\begin{array}{l}\text { F } \\
\text { Sig. }\end{array}$ & $\begin{array}{l}0.244 \\
0.622\end{array}$ & \\
\hline \multirow[t]{7}{*}{ t-test for Equality of Means } & $\mathrm{T}$ & 1.318 & 1.316 \\
\hline & Df & 402 & 395.280 \\
\hline & Sig.(2-tailed) & 0.188 & 0.189 \\
\hline & Mean Difference & 0.29481 & 0.29481 \\
\hline & Std. Error Difference & 0.22376 & 0.22410 \\
\hline & 95\% Confidence Lower & -0.14507 & -0.14578 \\
\hline & interval of the difference Upper & 0.73470 & 0.73540 \\
\hline
\end{tabular}

Table 5 showed that the group means are statistically insignificant because the value for equal variance assumed in the sig. (2-tailed) row is greater than 0.05 that is $(\mathrm{P}=.188>0.05), \mathrm{df}(402)=.395 .280, \mathrm{p}=.188$. Therefore the null hypothesis of no significant difference in the mean rating of male and female respondents on factors affecting the implementation of CSR by some IOC'S in host Communities of South-South, Nigeria is rejected. This implies that there is a significant difference in the mean ratings of male and female respondents on factors affecting the implementation of CSR by some IOC'S in host Communities of South-South, Nigeria.

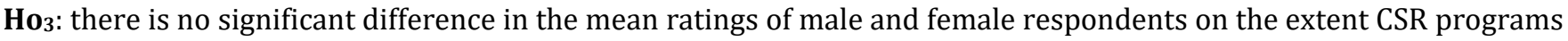
of Oil producing Companies has promoted better relationship with host Communities in the South-South of Nigeria.

Table 6 showed that the group means are statistically insignificant because the value for equal variance assumed in the sig. (2-tailed) row is greater than 0.05 that is $(\mathrm{P}=.8288>0.05), \mathrm{df}(400)=.393 .715, \mathrm{p}=.828$. Therefore, the null hypothesis of no significant difference in the mean rating of male and female respondents on the extent CSR programs of Oil producing Companies has promoted better relationship with host Communities in the South-South of Nigeria is rejected. This implies that there is a significant difference in the mean ratings of male and female respondents on the extent CSR programs of Oil producing Companies has promoted better relationship with host Communities in the South-South of Nigeria. 
Table 6 Independent Samples Test for male and female respondents on the extent CSR programs of Oil producing Companies has promoted better relationship with host Communities in the South-South of Nigeria

\begin{tabular}{|c|c|c|c|}
\hline & & \multicolumn{2}{|c|}{$\begin{array}{l}\text { Extent CSR programs of Oil Companies } \\
\text { promoted better relationship }\end{array}$} \\
\hline & & $\begin{array}{c}\text { Equal } \\
\text { variance } \\
\text { assumed }\end{array}$ & $\begin{array}{c}\text { Equal } \\
\text { variance not } \\
\text { assumed }\end{array}$ \\
\hline $\begin{array}{c}\text { Lavene's Test for } \\
\text { Equality of } \\
\text { Variances }\end{array}$ & $\begin{array}{l}\text { F } \\
\text { Sig. }\end{array}$ & $\begin{array}{l}0.041 \\
0.839\end{array}$ & \\
\hline \multirow{7}{*}{$\begin{array}{l}\text { t-test for Equality of } \\
\text { Means }\end{array}$} & $\mathrm{T}$ & -0.218 & -0.217 \\
\hline & Df & 402 & 393.715 \\
\hline & Sig.(2-tailed) & 0.828 & 0.828 \\
\hline & Mean Difference & -0.12972 & -0.12972 \\
\hline & Std. Error Difference & 0.59635 & 0.59743 \\
\hline & 95\% Confidence Lower & -0.30207 & -0.30427 \\
\hline & interval of the difference Upper & 1.04264 & 1.04483 \\
\hline
\end{tabular}

\section{Discussion}

\subsection{Corporate social responsibility of international oil companies as a panacea to conflict management strategy} in selected hosts communities in south-south of Nigeria

The findings in this regard showed that the conflict management strategies adopted by IOCs to mitigate conflicts between oil companies and host Communities in South-South, Nigeria, are: regular consultation, carrying out developmental projects, giving incentives to Chiefs and opinion leaders, participation in decision making by host communities, and provision of social amenities. The test of hypothesis showed that there is a significant difference in the mean ratings of male and female respondents on the on Significance of CSR as conflict management strategies by IOCs in hosts Communities in South-South, Nigeria. These findings agree with the assertion of [24], [25], [26] and [27] who stated that there is one and only one social responsibility of business -to use its resource and engage in activities designed to increase its profits so long as it stays within the rules of the game, which is to say, engages in open and free competition without deception or fraud. To ensure healthy and fraud free competition, businesses have always policed themselves on the theory of self-control. That is to say that CSR is a socially embedded construct, as the 'waves', 'issues' and 'modes' of CSR practices identified amongst IOCs in South-South reflect the firms' responses to their socio-economic context. This is aimed at developing host communities in the operational areas of corporate organisations to reduce certain conflicts that may arise consequentially with such assistance to the communities.

To further buttress these findings, [28], [29], [30] stated that $\mathrm{n}$ response to the increasing societal pressure, many companies adopt the concept of corporate social responsibility (CSR) by introducing codes of conduct that are expected to ensure socially responsible business practices throughout the chain - from supplier of raw materials to final end users. However, there are several challenges to the management and control of codes of conduct in global supply chains. Active commitment is a precondition for the successful implementation of the codes, but the incentive to comply with the codes does not necessarily extend to all the actors in the chain. Moreover, it is difficult to enforce codes of conduct in global supply chains, because the involved companies are separated geographically, economically, legally, culturally and politically [31], [32], [33]. In consequence, introducing codes of conduct in global supply chains raises a series of agency problems that may result in non-compliance. Realizing that non-compliance can have severe consequences for the initiator due to consumer sanctions. This suggests the lack of a systematic, focused, and institutionalized approach to CSR and that the understanding and practice of CSR in Nigeria are still grounded in the context of philanthropic action. 


\subsection{Factors affecting the implementation of the CSR by some IOCS in host communities south-south of Nigeria}

The findings in this regard revealed that the factors affecting the implementation of the CSR by some IOCs in host communities of South-South of Nigeria are: vandalization of facilities, volatile nature of host communities, autocratic approach of IOCs to host communities, hostile nature of host communities, and policies of IOCs on project implementation. The test of hypothesis showed that there is a significant difference in the mean ratings of male and female respondents on conflict management strategies using implementation of CSR by some IOCS in host Communities of South, Nigeria. These findings concur with the assertions of [34] who stated that since independence, the communities in South-South Nigeria have complained that they remain marginalized by a federation that is dominated by the ethnic majorities of the Hausa, Igbo and Yoruba. The entry of oil extraction into this conflict has added a new dynamic to the grievances of these communities. They have protested that oil revenues are not shared with local governments and thus that they continue to be excluded from economic gains, even when the oil is found in their communities [35].

\section{Conclusion}

The study's findings suggest that if oil companies avoid their social duties, oil-related conflicts will inevitably occur in host communities. For a cordial relationship, host communities must be fully included in the decision-making process of oil corporations on matters that affect them. Every Fortune 500 company has a functional CSR (Corporate Social Responsibility) department for such corrective and proactive crisis preventive actions.

\section{Recommendations}

Based on the findings of the study, the following recommendations were made;

- Host Communities should be mindful of their representations during negotiations

- Host Communities should protect the facilities of oil companies to keep them in operation as an act of inclusiveness and ownership in the oil company's operations.

- Host communities should be mainstreamed into the preparedness plan.

- The relationship between the Federal Government with the IOC's is also an impediment on the implementation of Corporate Social Responsibility (CSR)

\section{Compliance with ethical standards}

\section{Acknowledgments}

The authors wish to acknowledge the support of some of the oil companies operating in the region for releasing information about their social responsibility activities in the communities. We want to also acknowledge the support of the community chiefs and opinion leaders during data the collection

There is no conflict of interest among the authors.

\section{References}

[1] Ako R, Obokoh L, Okonmah P. Forging peaceful relationships between oil companies and host-communities in Nigeria's Delta region: A stakeholder's perspective to corporate social responsibility. Journal of Enterprising Communities: People and Places in the Global Economy. 2009; 3(2): 205-216.

[2] Amao 0. Corporate social responsibility, multinational companies and the law in Nigeria: Controlling multinationals in host states. Journal of African Law. 2008; 52(1): 89-113.

[3] Amao 0. Corporate social responsibility, human rights and the law: Multinational corporations in developing countries. New York: Routledge. 2011.

[4] Akpan W. Between responsibility and rhetoric: Some consequences of CSR practice in Nigeria's oil province. Development Southern Africa. 2006; 23(2): 223-240.

[5] Ananaba U, Chukwuka E. Corporate Social Responsibility and Its Implementation in Nigeria Problem and Prospects. Global Journal of Human Resources Management. 2016; 4(2): 66-69. 
[6] Anthony GH. The petroleum industry bill (PIB) and the issue of transparency and accountability in the extractive industry. In Ojo, G. U. (Ed.), Envisioning a posteconomy petroleum Nigeria: Leave oil in the soil. 2010; 141-150.

[7] Asgill S. The Nigerian Extractive Industries Transparency Initiative (NEITI): Tool for Conflict Resolution in the Niger Delta or Arena of Contested Politics? Critical African Studies. 2012; 7(9): 4-57.

[8] Ashgate. Pedamon C. Corporate social responsibility: A new approach to promoting integrity and responsibility. Company Lawyer. 2010; 31(6): 172-180.

[9] Boele R, Fabig H, Wheeler D. The Story of Shell, Nigeria and the Ogoni People - Environment, Economy, Relationships: Conflict and Prospects for Resolution." Sustainable Development. 2001; 9(7): 74-86.

[10] Bowen H. Social responsibilities of the businessman. New York: Harper \& Row. 1953.

[11] Godson-Ibeji H. Environmental Pollution is a widespread problem that influences both human health and agricultural productivity. Internal Journal of conflict Resolution. 2016; 5(9): 66-70.

[12] CAFOD. Unearth Justice: Counting the Cost of Gold. London. 2006.

[13] Gouldson A. Do firms adopt lower standards in poorer areas? Corporate social responsibility and environmental justice in the EU and the US. Area. 2006; 38(4): 402-412.

[14] Friuza M. History and development of Corporate social responsibility. Journal of Business and Economics. 2013; 4(6): 5-6.

[15] Frynas J. The False Development Promise of Corporate Social Responsibility: Evidence from Multinational Oil Companies." International Affairs. 2005; 81(3): 581-598.

[16] Frynas J. Beyond corporate social responsibility: Oil multinationals and social challenges. Cambridge University Press. 2009.

[17] Hans A, Bariki AH. Conflict management styles in oil and gas sector in Sultanate of Oman. International Journal of Information Technology and Business Management. 2012; 4(1): 1-15.

[18] Idemudia U. Conceptualising the CSR and development debate: Bridging existing analytical gaps. Journal of Corporate Citizenship. 2008; 29(1): 99-110.

[19] Ite A, Ibok UJ, Ite S, Petters W. Petroleum Exploration and Production: Past and Present...Environmental Issues in the Nigeria's Niger Delta. Lancaster Environment Centre, Lancaster University, Lancaster, United Kingdom. 2013.

[20] McWilliams A, Siegel D, Wright P. Corporate social responsibility: Strategic implications. Journal of Management Studies. 2006; 43(1): 1-18.

[21] MMSD. Breaking New Ground: Mining, Minerals, and Sustainable Development, World Business Council for Sustainable Development. 2002.

[22] Nigerian National Planning Commission. Meeting everyone's needs: National economic empowerment and development strategy. 2004.

[23] Obeta C. Corporate Environmental Responsibility: The Place of Multinational oil Companies in the Niger Delta in Nwosu and Soola edited communication. In Global, ICTs and Ecosystem Perspectives Insights from Nigeria, Enugu: Precision Publishers Limited. 2007.

[24] Okoye A. Theorising corporate responsibility as an essentially contested concept: Is a definition necessary? Journal of Business Ethics. 2009; 89(4): 613-627.

[25] Okonta A, Kemdi S. Economics of Violence: Petroleum Politics and Community Conflicts in the Nigeria Delta, Nigeria. 2004.

[26] Omeje KC. High stakes and stakeholders: Oil conflict and security in Nigeria. Aldershot. 2006.

[27] Osagie E. Causes of Conflicts in the Niger Delta Region of Nigeria as expressed by the Youth in Delta State. 2010.

[28] Oyefusi T. Oil and the Probability of Rebel Participation among youths in the Niger Delta. 2007.

[29] Pedamon C. Corporate social responsibility: A new approach to promoting integrity and responsibility. Company Lawyer. 2010; 31(6): 172-180.

[30] Peter U. Promoting Development through Corporate Social Responsibility- Does it work? International Journal of Social Science. 2003; 6(3): 12-15. 
[31] Phillips F. Corporate social responsibility in an African context. Journal of Corporate Citizenship. 2006; 24: 2327.

[32] Tuodolo F. Corporate social responsibility, local communities and TNCs in the oil and gas sector of Nigeria. Unpublished PhD Thesis, University of Liverpool, United Kingdom. 2007.

[33] Tuodolo F. Corporate social responsibility: Between civil society and oil industry in the developing world. ACME: An International E-Journal for Critical Geographies. 2009; 8(3): 530-541.

[34] Watts M. Resource Curse? Government, Oil and Power in the Niger Delta. Geopolitics. 2004; 9(1): 50-80.

[35] Whelan G, Muthuri JN. Chinese state-owned enterprises and human rights: The importance of national and intraorganizational pressures. Business \& Society (forthcoming). 2014. 